\title{
The interruption of the PDGF and EGF signaling pathways by curcumin stimulates gene expression of PPAR $\gamma$ in rat activated hepatic stellate cell in vitro
}

\author{
Yajun Zhou', Shizhong Zheng ${ }^{2}$, Jianguo Lin², Qian-Jin Zhang ${ }^{3}$ and Anping Chen ${ }^{2}$
}

Activation of hepatic stellate cells (HSC), the major effector in hepatic fibrogenesis, is coupled with sequential alterations in expression of genes, including the upregulation of platelet-derived growth factor- $\beta$ receptor (PDGF- $\beta$ R) and epidermal growth factor receptor (EGFR), as well as the down-regulation of the peroxisome proliferator-activated receptor- $\gamma$ (PPAR $\gamma$ ). However, the relationship among the alterations in expression of the genes and the activation of their signaling in activated HSC remains obscure. We recently showed that curcumin, the yellow pigment in curry, inhibited cell growth and induced gene expression of endogenous PPAR $\gamma$ in activated HSC in vitro. The present study is to elucidate the underlying mechanisms, focusing on the impacts of PDGF and EGF signaling. It is hypothesized that the interruption of the PDGF and EGF signaling pathways by curcumin might stimulate gene expression of PPAR $\gamma$ in activated HSC. Our results in this report indicate that the activation of PDGF or EGF signaling by exogenous PDGF or EGF inhibits PPAR gene expression in passaged HSC. Curcumin interrupts PDGF and EGF signaling demonstrated by inhibiting tyrosine phosphorylation of PDGF- $\beta$ R and EGFR and by reducing the levels of phosphorylated phosphatidylinositol-3 kinase (PI-3K/ AKT), extracellular signal-regulated kinase (ERK) and the Jun N-terminal kinase (JNK). The blockade of PI-3K/AKT, ERK or JNK signaling negatively regulates PPAR $\gamma$ gene expression in activated HSC, leading to the reduction in cell growth, including inducing cell arrest and apoptosis. Our results collectively demonstrate that the interruption of the PDGF and EGF signaling pathways by curcumin stimulates gene expression of PPAR $\gamma$ in activated HSC. These results provide novel insights into the mechanisms of curcumin in the induction of PPAR $\gamma$ gene expression in activated HSC.

Laboratory Investigation (2007) 87, 488-498. doi:10.1038/labinvest.3700532; published online 19 March 2007

KEYWORDS: hepatic fibrosis; hepatic stellate cell; polyphenol; signal pathways; gene expression

Hepatic stellate cells (HSC) are the most relevant cell type for the development of liver fibrosis. ${ }^{1,2}$ During liver injury, HSC become activated and trans-differentiate into myofibroblastlike cells. The process is called HSC activation. Enhanced HSC proliferation is a dramatic feature during the pathogenesis of liver fibrosis. It is mainly triggered by autocrine/ paracrine activation of the signaling for mitogenic plateletderived growth factor- $\beta$ (PDGF) and epidermal growth factor (EGF). ${ }^{3-6}$ The process of HSC activation is coupled with the up-expression of receptors for PDGF and EGF, ${ }^{4,7,8}$ as well as the dramatic down-expression of peroxisome proliferatoractivated receptor- $\gamma(\operatorname{PPAR} \gamma){ }^{9-11}$ Both PDGF- $\beta$ R and EGFR contain intrinsic tyrosine kinase activity. Upon binding to their ligands, the receptors become phosphorylated at tyrosine residues, leading to the activation of their downstream signaling, of which the mitogen-activated protein kinase (MAPK) pathways and the phosphatidylinositol 3-kinase (PI$3 \mathrm{~K})$ pathway are the major signaling routes. ${ }^{12,13}$ The MAPK family includes the extracellular signal-regulated kinase (ERK) pathway and the Jun N-terminal kinase (JNK) pathway. Activated PI-3K generates several phosphoinositols, leading to AKT activation by phosphorylation at $\mathrm{Thr}^{308}$ and Ser ${ }^{473}{ }^{14}$ which is inhibited by activation of phosphatase and tensin homolog (PTEN). ${ }^{13}$ It is well-known that these signaling pathways regulate multiple biological processes, including gene expression, cell proliferation and survival. ${ }^{12,13}$ PPARs belong to the superfamily of nuclear receptors. PPAR $\gamma$, one of the PPAR isoforms, is the most wildly studied. $\operatorname{PPAR} \gamma$ controls growth and differentiation in different tissues. Although the level of PPAR $\gamma$ is high in quiescent HSC in

\footnotetext{
'Department of Biochemistry, Nantong University, Nantong, China; ${ }^{2}$ Department of Pathology, School of Medicine, St Louis University, St Louis, MO, USA and

${ }^{3}$ Department of Cellular Biology and Anatomy, Louisiana State University Health Sciences Center in Shreveport, Shreveport, LA, USA

Correspondence: Dr A Chen, Phd, Department of Pathology, School of Medicine, St Louis University, 1402 S. Grand Blvd, St Louis, MO 63104, USA.

E-mail: achen5@slu.edu

Received 19 September 2006; revised 05 January 2007; accepted 07 January 2007
} 
normal liver, its expression and its activity are dramatically diminished during HSC activation in vitro and in vivo. ${ }^{9-11}$ Activation of PPAR $\gamma$ induces cell arrest and apoptosis of activated HSC. $^{9-11}$ Introduction of exogenous PPAR $\gamma$ cDNA is sufficient to reverse the morphology of activated HSC to the quiescent phenotype. ${ }^{15}$

Curcumin is the yellow pigment in curry from turmeric. It has received attention as a promising dietary supplement for cancer prevention ${ }^{16-18}$ and the protection against fibrogenic insults. ${ }^{19,20}$ However, the underlying mechanisms remain incompletely understood. ${ }^{21}$ We recently reported that curcumin induced gene expression of endogenous PPAR $\gamma$ in activated HSC in vitro, which was a prerequisite in the curcumin inhibition of HSC growth, induction of apoptosis and suppression of extracellular matrix gene expression. ${ }^{22-24}$ The aim of this study is to elucidate the mechanisms of curcumin in the induction of PPAR $\gamma$ gene expression in activated HSC, focusing on the impact of PDGF and EGF signaling. It is hypothesized that the interruption of the PDGF and EGF signaling pathways by curcumin might stimulate gene expression of PPAR $\gamma$ in activated HSC. Results in this report support our hypothesis and demonstrate that activation of PDGF or EGF signaling inhibits PPAR $\gamma$ gene expression. Curcumin interrupts PDGF and EGF signaling, leading to the induction of gene expression of PPAR $\gamma$ and the reduction of cell growth of activated HSC in vitro.

\section{MATERIALS AND METHODS}

\section{Materials}

Curcumin (purity $>94 \%$ ) was purchased from Sigma (St Louis, MO, USA) and used at $20 \mu \mathrm{M}$, unless indicated otherwise. PD68235, a specific PPAR $\gamma$ antagonist, was kindly provided by Pfizer (Ann Arbor, MI, USA). ${ }^{25}$ The PI-3K inhibitor LY294002 and the MEK inhibitor PD98059 were purchased from CalBiochem (La Jolla, CA, USA), and the JNK inhibitor SP600125 was purchased from Sigma. Recombinant PDGF and EGF were purchased from Cell Sciences (Canton, MA, USA).

\section{Isolation and Culture of HSC}

HSC were isolated from Sprague-Dawley rats (200-250 g) as we described previously. ${ }^{26}$ Cells were cultured in Dullbecco's modified Eagle's medium (DMEM) with $10 \%$ of fetal bovine serum (FBS). Semiconfluent HSC with 4-8 passages were used for experiments. In some of experiments, cells were serum-starved for $48 \mathrm{~h}$ in DMEM with $0.5 \%$ of FBS before treatment.

\section{Western Blotting Analyses}

Whole-cell extracts were prepared as we described. ${ }^{26}$ Proteins were separated by SDS-PAGE with $10 \%$ of resolving gel, and transferred to PVDF membrane. Target proteins were respectively detected by primary antibodies against PPAR $\gamma$, phosphorylated types of PDGF- $\beta$ R, EGFR, ERK1/2, JNK1/2 or AKT, and the corresponding non-phosphorylated types of total proteins; Bcl-2, Bax or cyclin D1, and subsequently by horseradish peroxidase-conjugated secondary antibodies (Santa Cruze Biotechnology, Santa Cruze, CA, USA). Protein bands were visualized by using a chemiluminescence reagent (Amersham Biosci, Piscataway, NJ, USA). In Western blotting analyses, the densities of bands were normalized with the internal invariable control $\beta$-actin. The level of target protein bands was densitometrically determined by using Quantity One ${ }^{\circledR}$ 4.4.1 (Bio-Rad). The variation in the density was expressed as fold changes compared to the control in the blot.

\section{RNA Isolation and Real-Time PCR}

Total RNA was extracted by using TRI-Reagent ${ }^{\circledR}$ (Sigma), following the protocol provided by the manufacturer. Real-time PCR was carried out as described previously. ${ }^{22}$ mRNA fold changes of target genes relative to the endogenous glyceraldehyde-3-phosphate dehydrogenase (GAPDH) control were calculated as suggested by Schmittgen et al. ${ }^{27}$ The following primers were used in real-time PCR:

$\operatorname{PPAR} \gamma:$

(F) 5'-ATTCTGGCCCACCAACTTCGG-3';

(R) 5'-TGGAAGCCTGATGCTTTATCCCCA-3';

GAPDH:

(F) 5'-GGCAAATTCAACGGCACAGT-3';

(R) $5^{\prime}$-AGATGGTGATGGGCTTCCC-3'.

\section{Plasmid Constructs}

The PPAR $\gamma$ promoter luciferase reporter plasmid pPPAR $\gamma$ Luc contain the $5^{\prime}$-flanking region $(-2776 \mathrm{bp})$ of the PPAR $\gamma$ gene promoter in a luciferase reporter plasmid. ${ }^{28}$ It was kindly provided by Dr Johan Auwerx (Pasteur Institute, Lille, France). ${ }^{28}$ The plasmid pdn-PTEN or pwt-PTEN contains a full-length of cDNA encoding the dominant-negative form of PTEN or wild-type PTEN, respectively. They were kindly provided by Dr Christopher G Kevil (Louisiana State University Health Sciences Center in Shreveport). The plasmid pdn-ERK or pdn-JNK, contains a full length of cDNA encoding the dominant-negative form of ERK or JNK respectively, which were described previously. ${ }^{29}$ The plasmid pa-ERK or pa-JNK contains cDNA encoding the constitutively active form of ERK or JNK, respectively, which were described previously. ${ }^{29,30}$

\section{Transient Transfection Assays}

Semiconfluent HSC in six-well plastic plates were transiently transfected with a reporter plasmid ( $3 \mu \mathrm{g}$ DNA/well, if no specific indication), by using LipofectAMINE ${ }^{\circledR}$ (Life Technologies), following the protocol provided by the manufacturer. Transfection efficiency was controlled by co-transfection of the $\beta$-galactosidase reporter plasmid pSV$\beta$-gal ( $1 \mu \mathrm{g} /$ well) (Promega). Luciferase activity was measured using an automated luminometer (Turners). $\beta$-Galactosidase assays were performed using an assay kit from Promega 
Corp. Each treatment had a triplicate in every experiment. Each experiment was repeated at least three times. Luciferase activity was expressed as relative unit after normalization with $\beta$-galactosidase activity.

\section{Analyses of Cell Growth}

The number of viable cells was used to determine cell growth by using CellTiter $96{ }^{\circledR}$ AQueous Non-Radioactive Cell Proliferation Assay kit (Promega) (ie MTS assays).

\section{Detection of Apoptotic HSC by TUNEL}

Pre-confluent HSC in slideflasks were serum starved for $24 \mathrm{~h}$. Cells were subsequently treated as described for an additional $24 \mathrm{~h}$. Cells were washed three times with cold PBS before fixation. Apoptotic HSC were detected by DeadEnd ${ }^{\mathrm{TM}}$ Fluorometric TUNEL System (Promega), following the protocol provided by the manufacturer.

\section{Flow Cytometric Analyses of Apoptotic HSC}

Semiconfluent HSC were treated as indicated. Cells were harvested by brief trypsin/EDTA treatment and washed several times with cold PBS. HSC $\left(\geq 1 \times 10^{6}\right.$ cells/each sample) were suspended in $2 \mathrm{ml}$ of FACS buffer (1\% FA buffer (Difco), $0.1 \%$ sodium azide and $1 \%$ FBS). Cells were fixed with ethanol, and then labeled with propidium iodide (PI; Sigma). Cells that were positively labeled with PI were detected by a Coulter ${ }^{\circledR}$ EPICS ${ }^{\circledR}$ XL-MCL flow cytometer. The rate of apoptosis was analyzed using its System $\mathrm{II}^{\mathrm{TM}}$ software, as described previously. ${ }^{31}$

\section{Statistical Analysis}

Differences between means were evaluated using an unpaired two-sided Student's $t$-test $(P<0.05$ was considered significant). Where appropriate, comparisons of multiple treatment conditions with control were analyzed by ANOVA with the Dunnett's test for post hoc analysis.

\section{RESULTS}

Exogenous PDGF or EGF Reduces Gene Expression of PPAR $\gamma$, which was Partially Eliminated by Curcumin

The process of HSC activation is coupled with the sequential upregulation of PDGF- $\beta$ R and EGFR and activation of their signaling, as well as the dramatic reduction in expression of PPAR $\gamma .{ }^{4-11}$ Prior other studies have suggested the opposite functions of PDGF and PPAR $\gamma$ in adipogenesis. ${ }^{32,33}$ To evaluate the effect of activation of PDGF and EGF signaling on regulation of gene expression of $\operatorname{PPAR} \gamma$, exogenous PDGF and EGF were added to passaged HSC for an additional $24 \mathrm{~h}$ after the treatment with or without curcumin in serum-free media for $24 \mathrm{~h}$. PPAR $\gamma$ expression was determined by realtime PCR and Western blotting analyses. Passaged HSC cultured in serum-depleted media respond better to the stimulation of PDGF or EGF. ${ }^{4,31}$ As shown in Figure 1, exogenous PDGF or EGF evidently inhibited PPAR $\gamma$ expression at both levels of mRNA and protein in a dose-dependent manner. Compared with the control with no treatment (the first black column on the left), EGF at $80 \mathrm{ng} / \mathrm{ml}$ or PDGF at $30 \mathrm{ng} / \mathrm{ml}$ reduced the steady-state level of $\operatorname{PPAR} \gamma \mathrm{mRNA}$ by 66 and 75\%, respectively (Figure 1a and c). The inhibitory effects of EGF and PDGF on the abundance of PPAR $\gamma$ were verified by Western blotting analyses (Figure $1 \mathrm{~b}$ and $\mathrm{d}$ ). However, if cells were preexposed to curcumin $(20 \mu \mathrm{M})$, the inhibitory effect of EGF or PDGF was significantly reduced (Figure 1). For instance, compared with cells exposed to EGF at $80 \mathrm{ng} / \mathrm{ml}$ or PDGF at $30 \mathrm{ng} / \mathrm{ml}$, the pre-exposure of cells to curcumin partially but significantly eliminated the reduction caused by EGF or PDGF, and increased the level of PPAR $\gamma$ mRNA by 2.4- and 2.25- fold, respectively (Figure 1a and c). This observation was verified by Western blotting analyses. In every pair of cells treated with the same dose of EGF (Figure 1b) or PDGF (Figure 1d), the pre-exposure of cells to curcumin significantly increased the level of $\operatorname{PPAR} \gamma$. These data collectively suggested that the activation of PDGF or EGF signaling by exogenous PDGF or EGF might suppress

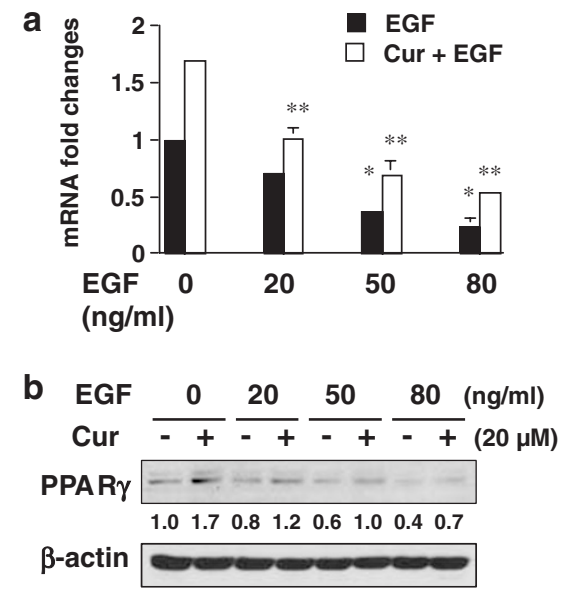

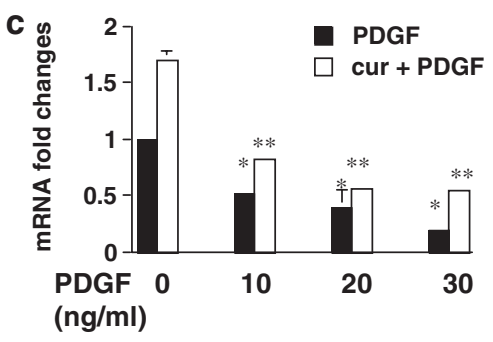

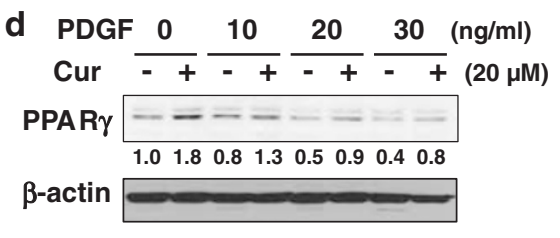

Figure 1 Exogenous EGF or PDGF dose-dependently reduces gene expression of PPAR $\gamma$ in activated HSC in vitro. After the treatment with or without curcumin in serum-free media for $24 \mathrm{~h}$, passaged HSC were stimulated with PDGF or EGF at indicated doses in serum-free media for an additional $24 \mathrm{~h}$. Total RNA or protein extracts were prepared from the cells for real-time PCR (a and $\mathbf{c})(n=3)$, or Western blotting analyses (b and $\mathbf{d})(n=3)$. $\beta$-Actin was used as an internal invariable control for (b and $\mathbf{d}$ ). The level of PPAR $\gamma$ was densitometrically normalized with $\beta$-actin. The numbers beneath the blots were fold changes in the densities of PPAR $\gamma$ bands compared to the control without treatment in the blot $(n=3)$. Because of the limited space, standard deviations were not presented. ${ }^{\star} P<0.05$ vs cells with no treatment (The first black column on the left). ${ }^{* * P}<0.05$ vs cells with only EGE or PDGF at the same dose. 
$\operatorname{PPAR} \gamma$ expression, which could be partially eliminated by curcumin.

\section{Curcumin Reduces Tyrosine Phosphorylation of PDGF- $\beta$ R and EGFR}

Additional experiments were performed to elucidate the effect of curcumin on tyrosine phosphorylation of PDGF- $\beta \mathrm{R}$ and EGFR in activated HSC, which might lead to interruption of the signaling pathways of PDGF and EGF and inactivation of downstream MAPK and PI-3K/AKT. Pilot studies indicated that the peak of tyrosine phosphorylation of PDGF- $\beta$ R or EGFR was within 15-20 min after the addition of FBS, which contains significant amounts of PDGF and $\mathrm{EGF}^{4,31}$ and that the process lasted no less than $60 \mathrm{~min}$ (data not shown). Cells were serum-starved in DMEM for $48 \mathrm{~h}$, which made cells more sensitive to serum stimulation. ${ }^{22-24}$ Serum-starved cells were pretreated with curcumin for $30 \mathrm{~min}$ before the stimulation with FBS (10\%) for an additional $20 \mathrm{~min}$. Whole-cell extracts were prepared. Phosphorylated PDGF- $\beta$ R and EGFR were detected by Western blotting analyses using antibodies against phospho-PDGF- $\beta$ R (1:2000) and EGFR (1:500), respectively. As shown in Figure 2, curcumin significantly and dose-dependently reduced tyrosine phosphorylation of PDFG- $\beta$ R (Figure 2a) and EGFR (Figure 2b) in HSC. As controls, the levels of total PDFG- $\beta$ R (Figure 2a) and EGFR (Figure 2b) were not changed. These results suggested that curcumin might interrupt PDGF and EGF signaling by reducing receptor tyrosine phosphorylation in passaged HSC.

\section{Curcumin Blocks the Activation of the ERK, JNK and PI-3K/AKT Signaling Pathways in Activated HSC}

The ability of curcumin to interrupt PDGF and EGF signaling was verified by evaluating the effects of curcumin on the activity of ERK, JNK and AKT. Pilot studies indicated that the peak of tyrosine phosphorylation of PDGF- $\beta \mathrm{R}$ or EGFR was within 15-20 min after the stimulation with FBS (data not shown). Serum-starved HSC were pretreated with curcumin for 30 min before the stimulation with FBS (10\%) for an additional $20 \mathrm{~min}$. Whole-cell extracts were prepared. As shown in Figure 3 by Western blotting analyses, curcumin dose-dependently reduced the level of phosphorylated ERK (Figure 3a), JNK (Figure 3b) and AKT (Figure 3c). In great contrast, the phyto-chemical had no impact on the level of total ERK, JNK and AKT (Figure 3). These results suggested that curcumin might block the activation of the ERK, JNK and PI-3K/AKT signaling pathways in passaged HSC, which confirmed the effect of curcumin on the interruption of PDGF and EGF signaling in HSC.

\section{Alterations in ERK, JNK or PI-3K/AKT Activity Change the Promoter Activity of PPAR $\gamma$ Gene in Activated HSC}

Our results suggested that the activation of PDGF and EGF signaling might suppress gene expression of PPAR $\gamma$ in activated HSC (Figure 1). It was, therefore, assumed that

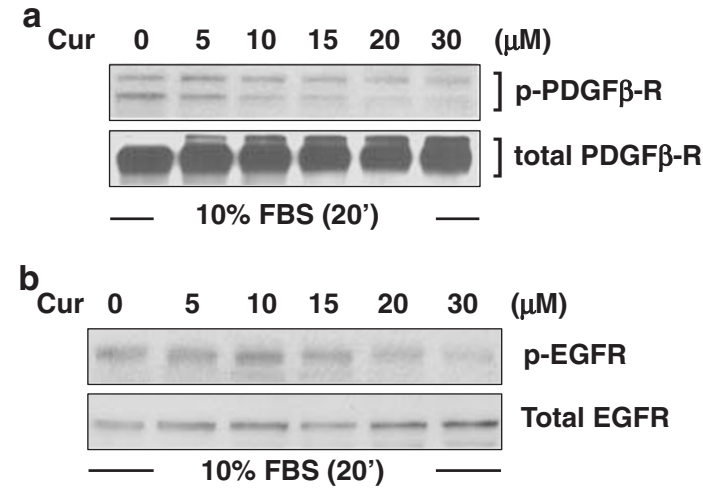

Figure 2 Curcumin dose-dependently reduces tyrosine phosphorylation of PDGF- $\beta$ R and EGFR in activated HSC in vitro. After serum-starvation for $48 \mathrm{~h}$, HSC were pretreated with curcumin for 30 min before the stimulation with FBS (10\%) for an additional $20 \mathrm{~min}$. Whole-cell extracts were prepared for Western blotting analyses. Representatives were shown here from three independent experiments. (a) Curcumin dose-dependently reduces the level of phosphorylatetd PDGF- $\beta$ R (p-PDGF- $\beta$ R). Total PDGF- $\beta$ R was used as an internal control. (b) Curcumin dose-dependently reduces the level of phosphorylatetd EGFR ( $p$-EGFR). Total EGFR was used as an internal control. a

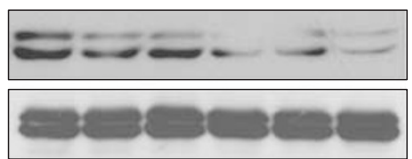

p-ERK1/2

Total

ERK1/2

b

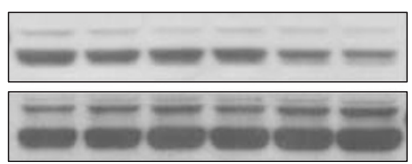

p-JNK1/2

Total JNK1/2

C

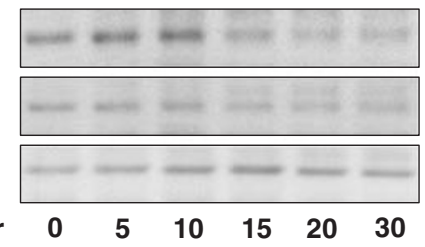

p-AKT ${ }^{\text {ser473 }}$

p-AKT $T^{\text {thr308 }}$

Total AKT

$(\mu \mathrm{M})$
Figure 3 Curcumin blocks the activation of the ERK, JNK and PI-3K/AKT signaling pathways in activated HSC in vitro. After serum-starvation for $48 \mathrm{~h}$, HSC were pre-treated with curcumin for $30 \mathrm{~min}$ before the stimulation with FBS (10\%) for an additional $20 \mathrm{~min}$. Whole cell extracts were prepared for Western blotting analyses. Representatives were shown from three independent experiments. (a) Curcumin reduces the level of phosphorylatetd ERK1/2 (p-ERK1/2). Total ERK1/2 was used as an internal control. (b) Curcumin reduces the level of phosphorylatetd JNK1/2 (p-JNK1/2). Total JNK1/2 was used as an internal control for equal loading. (c) Curcumin reduces the level of phosphorylatetd AKT ( $\mathrm{p}-\mathrm{AKT}^{\text {ser473 }}$ and $\left.\mathrm{p}-\mathrm{AKT}^{\mathrm{thr} 308}\right)$. Total AKT was used as an internal control.

stimulation or inhibition of the activity of the downstream inter-mediators of the signaling, for example, ERK, JNK or PI-3K/AKT, might respectively result in the reduction or induction of gene expression of PPAR $\gamma$ in HSC. To test the assumption, HSC were co-transfected with pPPAR $\gamma$-Luc plus a cDNA expressing plasmid of pa-ERK, pa-JNK or 
pwt-PTEN, or a plasmid of pdn-ERK, pdn-JNK or pdnPTEN. The plasmid pPPAR $\gamma$-Luc is a PPAR $\gamma$ promoter luciferase reporter plasmid, which contains the $5^{\prime}$-flanking region $(-2776 \mathrm{bp})$ of the PPAR $\gamma$ gene promoter subcloned in a luciferase reporter plasmid. ${ }^{34}$ The cDNA expression plasmid pa-ERK, or pa-JNK, contains a fragment of cDNA encoding the constitutively active form of ERK (a-ERK), or JNK (a-JNK), respectively. The plasmid pwt-PTEN contains a full size of wild-type PTEN cDNA, which inhibits activation of PI-3K/AKT signaling. ${ }^{35}$ Similarly, the plasmid pdn-ERK, pdn-JNK or pdn-PTEN contains a fragment of cDNA encoding the dominant-negative form of ERK (dn-ERK), JNK (dn-JNK) or PTEN (dn-PTEN), respectively. A total of 3.2 or $4.5 \mu \mathrm{g}$ of plasmid DNA per well was used for the co-transfection of HSC in six-well culture plates. It included $2 \mu \mathrm{g}$ of pPPAR $\gamma$-Luc, $0.5 \mu \mathrm{g}$ of pSV- $\beta$-gal, and $0.7 \mu \mathrm{g}$ (Figure $4 \mathrm{a}$ and d), or $2 \mu \mathrm{g}$ (Figure $4 \mathrm{~b}$ and c) of a cDNA-expressing plasmid at indicated doses and the empty vector pcDNA. The latter was used to ensure an equal amount of total DNA in transfection assays. After transfection, cells were serum-starved in DMEM for $24 \mathrm{~h}$ before the stimulation with FBS (10\%) in the presence or absence of curcumin $(20 \mu \mathrm{M})$ for an additional $24 \mathrm{~h}$. As shown in Figure 4 by luciferase assays, compared with no treatment (the first columns on the left), the activation of ERK, JNK or PI-3K/AKT, respectively, by pa-ERK, pa-JNK (Figure 4a), or by pdn-PTEN (Figure 4c), significantly reduced luciferase activity. These results suggested that the activation of ERK, JNK or PI-3K/AKT signaling might inhibit the gene promoter activity of PPAR $\gamma$ in HSC. Curcumin, as expected, dramatically stimulated the promoter activity of PPAR $\gamma$ demonstrated by the increase in luciferase activity (the third columns on the left in Figure 4a and c). It was of interest to observe that the activation of ERK, JNK, or PI-3K/AKT, by pa-ERK, pa-JNK (Figure 4a), or by pdn-PTEN (Figure 4c), dose-dependently eliminated the stimulatory effect of curcumin on luciferase activity. In great contrast, the blockade of these signaling pathways by pdnERK, pdn-JNK (Figure 4b), or by pwt-PTEN (Figure 4d) caused a dose-dependent increase in luciferase activity. Wildtype PTEN acts as an 'off' switch for PI-3K signaling. ${ }^{35}$ These results collectively suggested that the alterations in the activity of ERK, JNK or PI-3K/AKT might negatively regulate the promoter activity of PPAR $\gamma$ gene, leading to changes in gene expression of PPAR $\gamma$ in HSC.

\section{The Inhibition of ERK, JNK or PI-3K/AKT Activity Stimulates Gene Expression of PPAR $\gamma$ in Activated HSC} Chemicals LY294002 (LY), PD98059 (PD) and SP600125 (SP) are commonly used for specifically inhibiting the activity of PI-3K/AKT, ERK and JNK, respectively. To further test the assumption that the alteration of the activity of PDGF and EGF signaling might negatively regulate expression of $\operatorname{PPAR} \gamma$ gene in HSC, these chemicals were respectively used to selectively inhibit ERK, JNK or PI-3K. Semiconfluent HSC were transfected with the PPAR $\gamma$ promoter luciferase reporter plasmid pPPAR $\gamma$-Luc. After recovery overnight, cells were serum-starved for $24 \mathrm{~h}$ in DMEM with $0.5 \%$ of FBS. Cells were pretreated with PD98059, SP600125 or LY294002 at various concentrations, or with curcumin at $20 \mu \mathrm{M}$, for $30 \mathrm{~min}$ before the stimulation with FBS (10\%) for an a

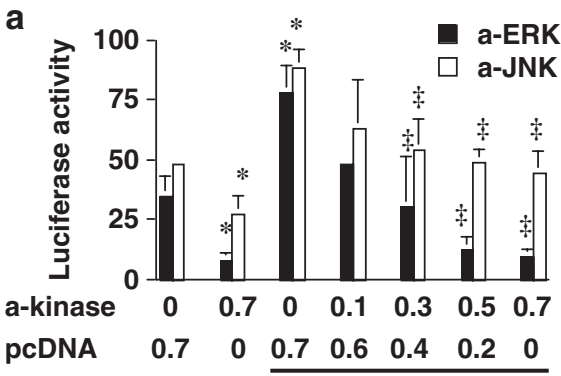

Curcumin $(20 \mu \mathrm{M})$

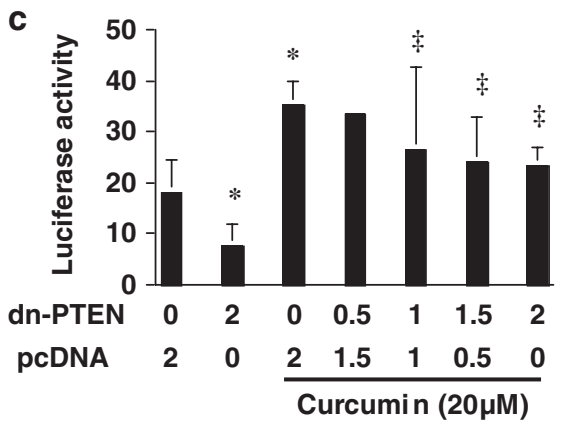

b

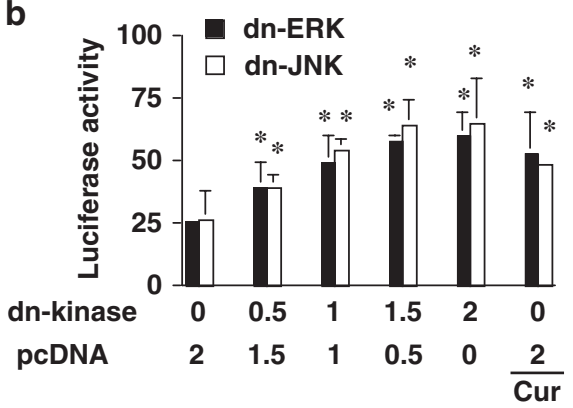

d

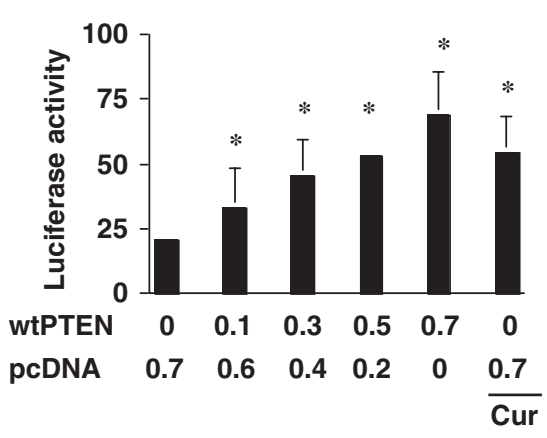

Figure 4 Alterations in ERK, JNK or PI-3K/AKT activity change the promoter activity of PPAR $\gamma$ gene in activated HSC. HSC in six-well plates were co-tranfected with a fixed amount of a DNA mixture per well. It includes $2 \mu \mathrm{g}$ of pPPAR $\gamma$-Luc, $0.5 \mu \mathrm{g} \mathrm{pSV-} \beta$-gal and a plasmid expressing the active form of a kinase, that is, pa-ERK, pa-JNK, or pwt-PTEN, or a plasmid expressing the dominant negative form of a kinase, that is, pdn-ERK, pdn-JNK, or pdn-PTEN, plus the empty vector pcDNA. The latter was used to ensure the equal amount of total DNA in transfection assays. The amount of DNA of pa-ERK, pa-JNK, or pwt-PTEN plus pcDNA was equalized to $0.7 \mu \mathrm{g}$ (a and $\mathbf{d}$ ). The amount of DNA of pdn-ERK, pdn-JNK, or pdn-PTEN plus pcDNA was equalized to $2 \mu \mathrm{g}$ (b and $\mathbf{c}$ ). After recovery overnight, cells were serum-starved in DMEM for $24 \mathrm{~h}$ before the stimulation with FBS $(10 \%)$ in the presence or absence of curcumin $(20 \mu \mathrm{M})$ for an additional $24 \mathrm{~h}$. Luciferase activities were expressed as relative units after $\beta$-galactosidase normalization $(n \geq 6) .{ }^{*} P<0.05$ vs cells with no treatment (the corresponding first column on the left). ${ }^{\ddagger} P<0.05$ vs cells with curcumin only, without co-transfected pa-kinase or pdn-PTEN (the corresponding third column on the left). 
additional $24 \mathrm{~h}$. As shown earlier in Figures 1 and 2, FBS (10\%) contained enough PDGF and EGF to activate their signaling in serum-starved HSC. Luciferase assays in Figure 5 a demonstrated that each of the three specific inhibitors, like curcumin, caused a dose-dependent increase in luciferase activity, suggesting that the inhibition of ERK, JNK or PI-3K might stimulate the activity of the promoter of $\operatorname{PPAR} \gamma$ gene in passaged HSC.

To confirm the observation, serum-starved HSC were pretreated with LY294002 (LY), PD98059 (PD), or SP600125 (SP), at various concentrations, or with curcumin (Cur) at $20 \mu \mathrm{M}$, for $30 \mathrm{~min}$ before the stimulation with FBS (10\%) for an additional $24 \mathrm{~h}$. Gene expression of PPAR $\gamma$ was evaluated by real-time PCR (Figure 5b) and Western blotting analyses (Figure $5 c$ ). As shown in Figure $5 b$ and c, compared with the control with no treatment (the second columns, or wells on the left), curcumin, as expected, significantly increased gene expression of PPAR $\gamma$ (the first columns, or wells on the left). It was further observed that the treatment of HSC with each of the inhibitors led to a dose-dependent increase in PPAR $\gamma$ expression at the levels of mRNA (Figure $5 \mathrm{~b}$ ) and protein (Figure $5 \mathrm{c}$ ). Taken together, these results indicated that the inhibition of ERK, JNK or PI-3K/AKT activity stimulated gene expression of PPAR $\gamma$, which supported the assumption that alteration of the activity of PDGF and EGF signaling might negatively regulate the expression of PPAR $\gamma$ gene in HSC.

\section{The Blockade of the PI-3K/AKT, ERK, and/or JNK Signaling Pathways Results in the Reduction in HSC Growth, which is Partially Eliminated by Inhibition of PPAR $y$ Activation}

Substantial evidence has indicated that the activation of PI3K/AKT, JNK and/or ERK stimulates HSC proliferation. ${ }^{6,36,37}$ We have previously demonstrated that the activation of $\operatorname{PPAR} \gamma$ was required for curcumin to inhibit HSC proliferation. ${ }^{23}$ Our earlier study showed that curcumin inhibited PI-3K/AKT, ERK, and JNK activity (Figure 3) and that the interruption of the signaling pathways for PI-3K/AKT, ERK and JNK induced gene expression of PPAR $\gamma$ (Figures 4 and 5). Prior experiments suggested that $10 \%$ of FBS might contain enough agonists to activate PPAR $\gamma$ in HSC. ${ }^{11,22-24}$ The induction of $\operatorname{PPAR} \gamma$ expression resulted in the stimulation of its activity in cultured HSC. ${ }^{22-24}$ It is of interest to evaluate the role of PI-3K/AKT, ERK, and JNK activity in the curcumin induction of gene expression of PPAR $\gamma$. Serumstarved HSC were divided into two groups. One group was treated with curcumin $(20 \mu \mathrm{M})$, LY294002 (LY), PD98059 (PD) or SP600125 (SP) at the indicated concentrations, or with a mixture of the three inhibitors at the indicated concentrations in DMEM with FBS (10\%) for $24 \mathrm{~h}$. The other group was pretreated with the specific PPAR $\gamma$ inhibitor $\mathrm{PD} 68235\left(\mathrm{PD}^{\prime}\right)$ at $20 \mu \mathrm{M}$ for $30 \mathrm{~min}$ before the addition of curcumin $(20 \mu \mathrm{M})$, or each of the above-specific inhibitors, or the mixture of the inhibitors, at the indicated concentra-
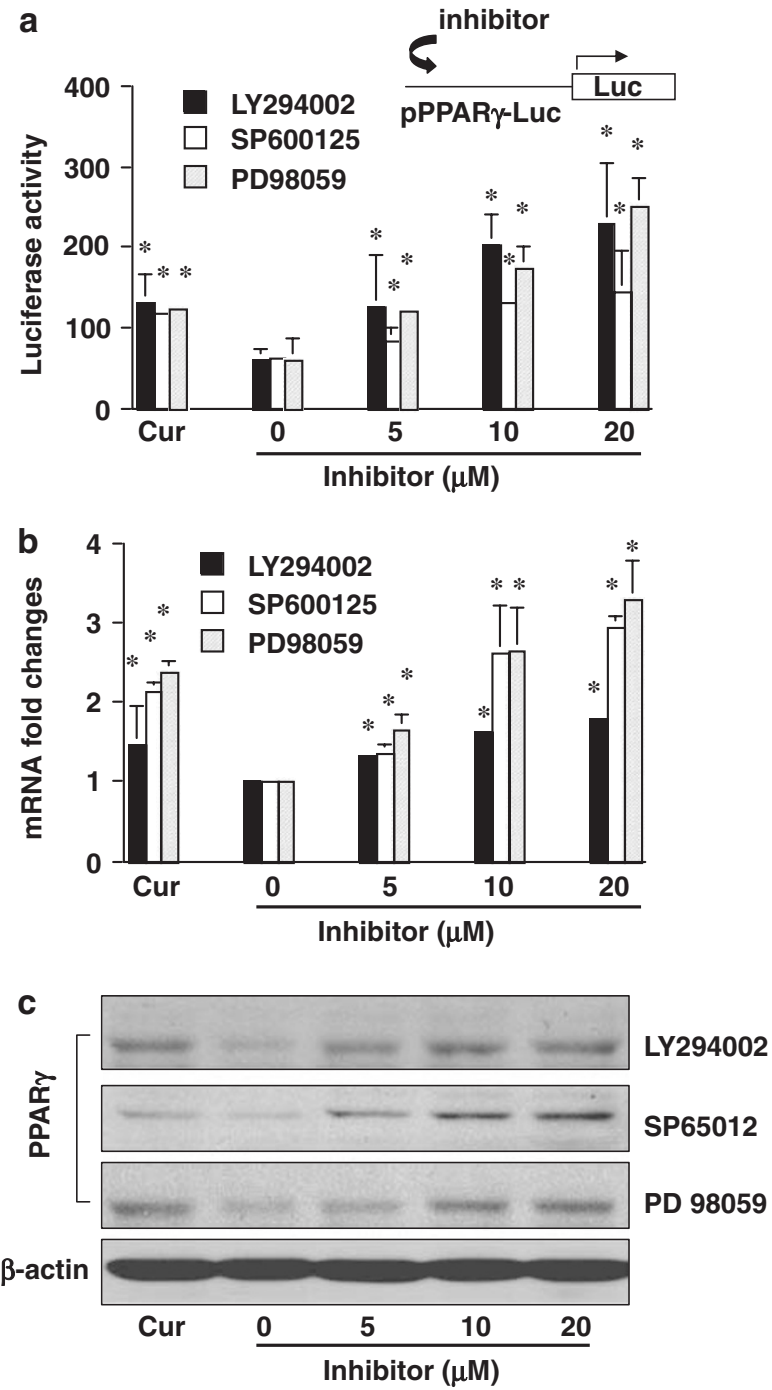

Figure 5 The inhibition of ERK, JNK or PI-3K/AKT activity stimulates gene expression of PPAR $y$ in activated HSC. With or without transfection, serumstarved HSC were respectively pretreated with or without LY294002 (a PI-3K inhibitor), SP600125 (a JNK inhibitor), or PD98059 (a MEK inhibitor) at indicated doses, or with curcumin at $20 \mu \mathrm{M}$, for 30 min before the stimulation with FBS (10\%) for an additional $24 \mathrm{~h}$. (a) Luciferase assays of cells transfected with pPPAR $\gamma$-Luc, containing a fragment of PPAR $\gamma$ gene promoter in a luciferase reporter plasmid. Luciferase activities were expressed as relative units after $\beta$-galactosidase normalization $(n \geq 6)$. The floating schema denotes the pPPAR $\gamma$-Luc luciferase reporter construct in use and the application of an inhibitor to the system. ${ }^{*} P<0.05$ vs cells with no treatment (the second columns on the left). (b) Real-time PCR analyses of PPAR $\gamma$ mRNA $(n=3) .{ }^{\star} P<0.05$ vs cells with no treatment (the second columns on the left); (c) Western blotting analyses of PPAR $\gamma$. Representatives were shown here from three independent experiments.

tions in the media with FBS (10\%) for an additional $24 \mathrm{~h}$. Cell growth was determined by numbers of viable cells using MTS assays. Results were expressed as changes in viable cells, compared to the cells with no treatment. As shown in Table 1, for the first group, which had no pretreatment to inhibit the 
Table 1 The blockade of the PI-3K/AKT, ERK and/or JNK signaling pathways results in the reduction in HSC growth, which is partially eliminated by the inhibition of PPAR $\gamma$ activation

$\mathrm{PD}^{\prime}$

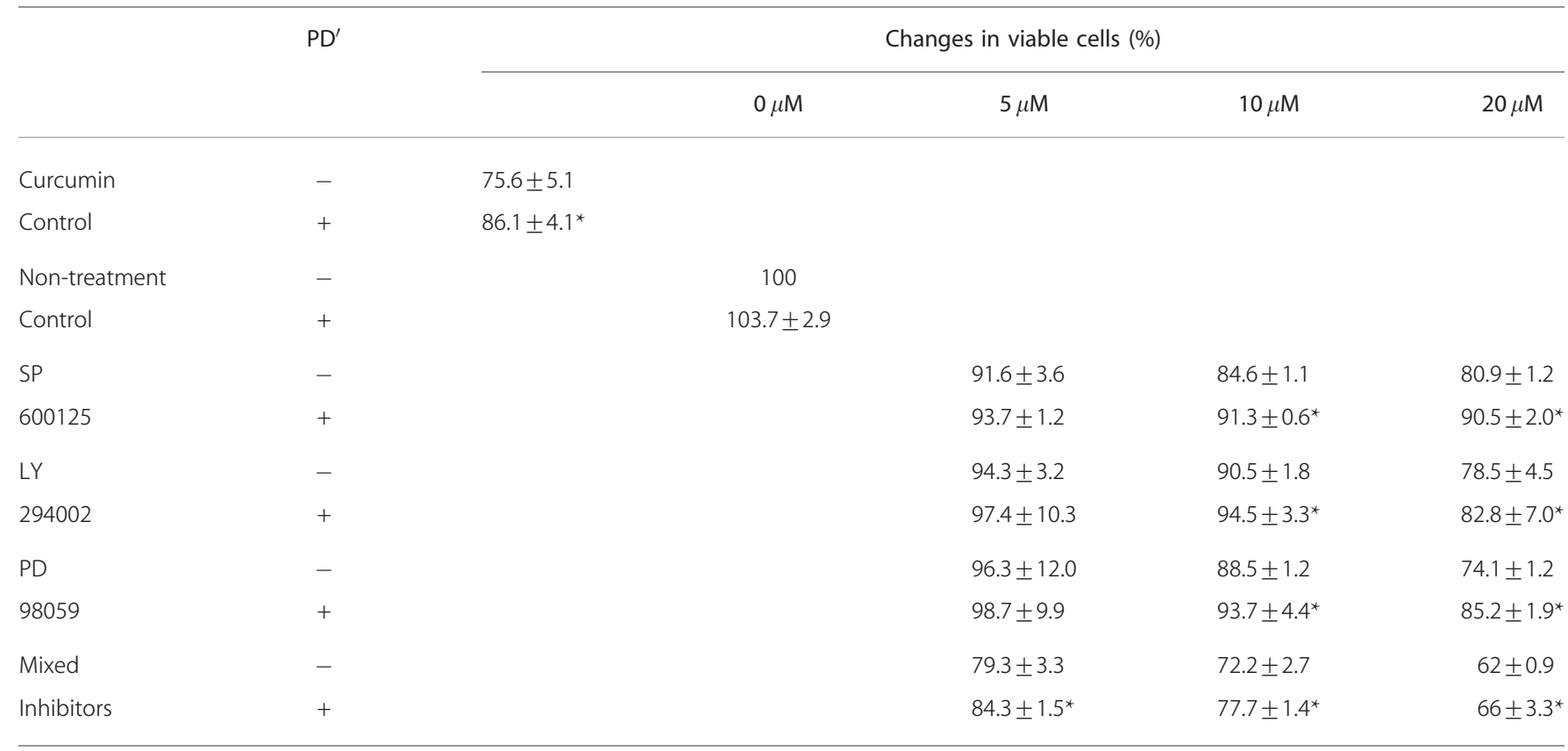

Serum-starved HSC were treated with or without curcumin $(20 \mu \mathrm{M})$, or LY294002 (LY), or PD98059 (PD), or SP600125 (SP), or a mixture of the three inhibitors at the indicated concentrations in DMEM with FBS $(10 \%)$ for $24 \mathrm{~h}$ in the presence or absence of the PPAR $\gamma$ antagonist PD68235 (PD') at $20 \mu \mathrm{M}$. Cell growth was analyzed by MTS assays. Results were expressed as changes in viable cells (\%) (Means \pm s.d.) ( $n 3$ ), compared to the negative control with no treatment. ${ }^{\star} P<0.05$ versus cells with the same specific inhibitor at the same concentration.

activation of PPAR $\gamma$, LY294002, SP600125 or PD98059, like curcumin, reduced the number of viable cells of HSC in a dose-dependent manner. On comparing to each of the individual inhibitor, the mixture of the three inhibitors had a more potent inhibitory effect on HSC growth. For the second group, which had the pretreatment, it is of interest to observe that the inhibition of $\operatorname{PPAR} \gamma$ activation by the pretreatment of cells with PD68235 (PD') partially, but significantly, eliminated the inhibitory effect of each of the inhibitors, as well as the mixture of the three inhibitors (Table 1). Taken together, these results indicated that the blockade of the PI-3K/AKT, JNK and/or ERK signaling pathways resulted in the reduction in HSC growth, which was partially eliminated by inhibition of PPAR $\gamma$ activation. These results collectively suggested that the inhibition of cell growth of HSC by curcumin might result from the blockade of the PI-3K/AKT, ERK and JNK signaling, leading to the induction of gene expression of PPAR $\gamma$.

\section{The Interruption of the PI-3K/AKT, ERK and JNK Signaling Pathways Induces Apoptosis of Activated HSC, which is Partially Counteracted by Inhibition of PPAR $\gamma$ Activation}

Our prior results indicated that $\operatorname{PPAR} \gamma$ activation was a prerequisite in the curcumin induction of apoptosis of HSC. ${ }^{22,23}$ Additional experiments were performed to evaluate the effect of the interruption of the PI-3K/AKT, ERK and
JNK signaling pathways on the curcumin induction of apoptosis of HSC. Serum-starved HSC were similarly divided into two groups, and pretreated with or without the specific PPAR $\gamma$ inhibitor PD68235 $\left(\mathrm{PD}^{\prime}\right)(20 \mu \mathrm{M})$ for $30 \mathrm{~min}$ before the addition of curcumin $(20 \mu \mathrm{M}), \mathrm{LY} 294002$ (LY), PD98059 (PD) or SP600125 (SP) at the indicated concentrations in the media with FBS (10\%) for an additional $24 \mathrm{~h}$. A portion of the cells was used for determination of apoptosis by flow cytometric analyses. Whole-cell extracts from the rest of the cells were prepared for analyses of cyclin D1 (Cln D1), a critical protein in stimulating cell cycle at the stage of $G_{0} / G_{1}$, and the apoptosis relevant proteins Bax and Bcl-2. As shown in Figure 6 by Western blotting analyses, compared with the control with no treatment (the second well in each blot), like curcumin (the first well in each blot), each of the inhibitors caused a dose-dependent reduction in the abundance of cyclin D1. On comparing with the control (the left well in each pair of a kinase inhibitor at the same dose), the pretreatment with the specific PPAR $\gamma$ inhibitor partially eliminated the inhibitory effect of the kinase inhibitor and increased the abundance of cyclin D1 (the right well in each pair). The levels of Bcl-2 and Bax determine the fate of cells, that is, survival or apoptosis. Also as shown in Figure 6, compared with the control with no treatment (the second well in each blot), curcumin, as expected, increased the level of proapoptotic Bax and reduced the abundance of antiapoptotic Bcl-2 (the first well in each blot). Like curcumin, each of 


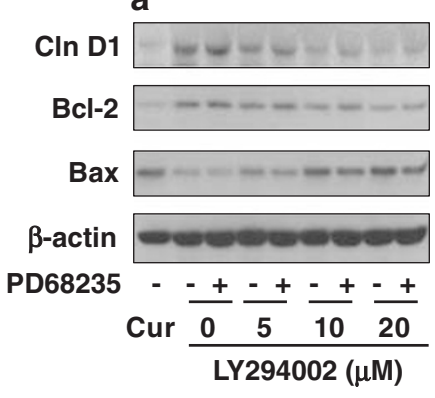

b

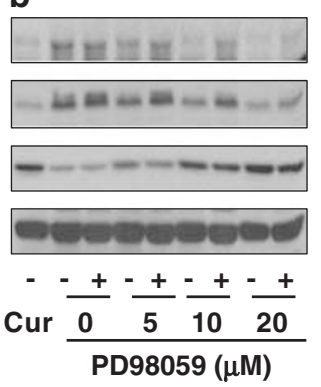

C

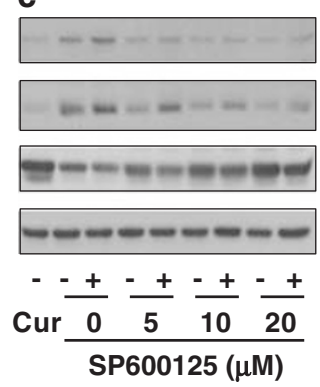

Figure 6 The interruption of PI-3K/AKT, JNK or ERK signaling alters the expression of proteins relevant to cell cycle and apoptosis in activated HSC. Serumstarved HSC were divided into two groups. One group was treated with curcumin $(20 \mu \mathrm{M})$, or one of the kinase inhibitors at the indicated concentrations, in DMEM with FBS (10\%) for $24 \mathrm{~h}$. The other group was pretreated with PD68235, a specific PPAR $\gamma$ inhibitor, at $20 \mu \mathrm{M}$ for $30 \mathrm{~min}$ before the addition of curcumin $(20 \mu \mathrm{M})$, or one of the inhibitors at the indicated concentrations in the media with FBS (10\%) for an additional $24 \mathrm{~h}$. Whole-cell extracts were prepared for Western blotting analyses. The levels of the cell cycle-stimulating protein Cyclin D1, the antiapoptotic protein $\mathrm{BCl}-2$ and the proapoptotic protein Bax were, respectively, detected. Representatives from three independent experiments were shown. (a) Cells were treated with LY294002 with or without the PPAR $\gamma$ antagonist PD68235; (b) Cells were treated with PD98059 with or without the PPAR $\gamma$ antagonist PD68235; (c) Cells were treated with SP600125 with or without the PPAR $\gamma$ antagonist PD68235.

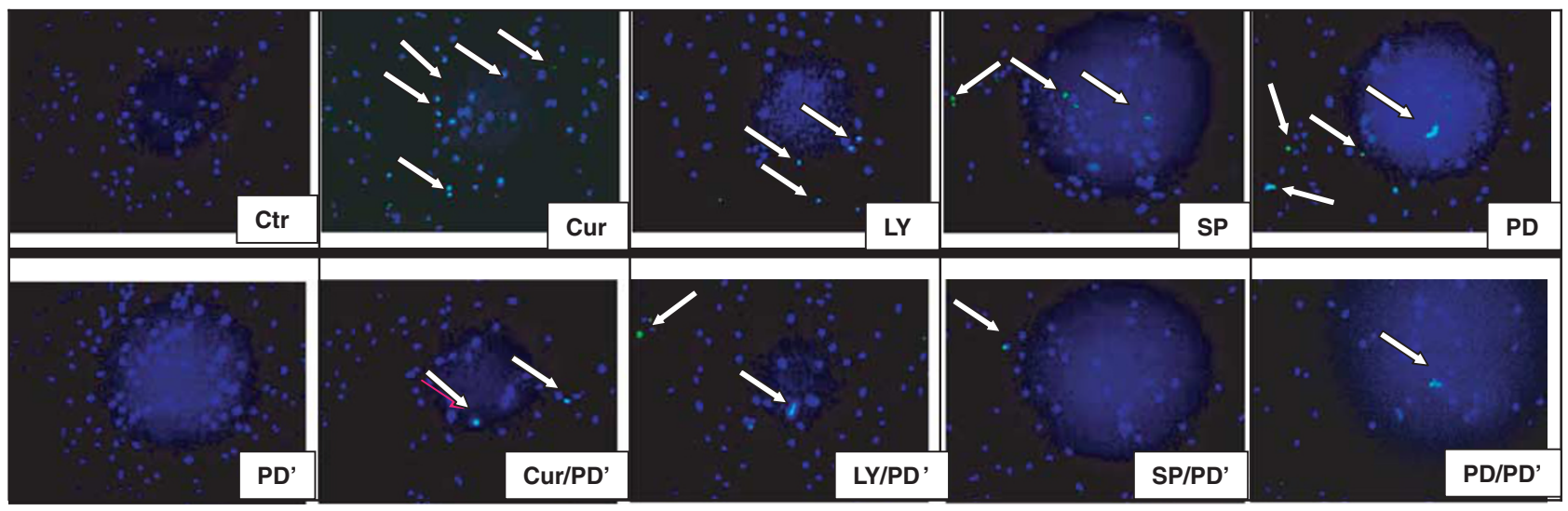

Figure 7 The blockade of the PI-3K/AKT, ERK, and/or JNK signaling pathways results in the induction of apoptosis, which is partially eliminated by the inhibition of PPAR $\gamma$ activation. Serum-starved HSC were treated with or without curcumin $(20 \mu \mathrm{M})$ ) or LY294002 (LY) (10 $\mu \mathrm{M})$, or PD98059 (PD) (10 $\mu \mathrm{M})$, or SP600125 (SP) $(10 \mu \mathrm{M})$ for $24 \mathrm{~h}$ in the presence or absence of the PPAR $\gamma$ antagonist PD68235 (PD') at $20 \mu \mathrm{M}$. Apoptotic HSC were detected by DeadEnd ${ }^{\mathrm{TM}}$ Fluorometric TUNEL System (Promega) and viewed using a fluorescent microscope. Nuclei of apoptotic cells were detected and labeled with green fluorescence indicated by arrows. Nuclei of HSC were stained in blue with DAPI. Representative views $(n=3)$ from each treatment were presented (original $\times 40$ ).

the inhibitors caused a dose-dependent reduction in the abundance of Bcl-2 and an increase in the level of Bax. Inhibition of PPAR $\gamma$ activation by the pretreatment with PD68235 partially abrogated the ability of the inhibitors to alter the levels of the proteins relevant to apoptosis. The ability of the inhibitors to induce apoptosis was confirmed by TUNEL staining (Figure 7) and by flow cytometric analyses (Table 2). Similarly, this ability was partially eliminated by inhibition of PPAR $\gamma$ activation with PD68235 (PD'). Taken together, these results demonstrated that the blockade of the PI-3K/AKT, ERK and JNK signaling pathways induced apoptosis of activated HSC, which was partially counteracted by inhibition of PPAR $\gamma$ activation.

\section{DISCUSSION}

HSC activation is mainly triggered by the release of mitogenic PDGF, EGF and fibrogenic transforming growth factor$\beta 1$ (TGF- $\beta 1$ ) from Kupffer cells and activated HSC. ${ }^{38}$ The process of HSC activation is coupled with the sequential up-expression of receptors for growth factors, including PDGF- $\beta$ R, type I \& II receptors for TGF- $\beta^{39,40}$ and EGFR. ${ }^{8}$ In addition, HSC activation coincides with a dramatic reduction in the abundance PPAR $\gamma{ }^{9-11}$ We previously proposed an antagonistic relationship between the activation of the signaling pathways for these growth factors and the gene expression of PPAR $\gamma$ in HSC, that is, activation of the signaling pathways reduces the activity of PPAR $\gamma$ by suppressing 
Table 2 The blockade of PI-3K/AKT, JNK or ERK signaling increases the rate of apoptosis in passaged HSC, which is partially counteracted by the inhibition of PPAR $\gamma$ activation

\begin{tabular}{|c|c|c|c|c|c|c|}
\hline & \multirow[t]{2}{*}{$\mathrm{PD}^{\prime}$} & \multicolumn{5}{|c|}{ Distributions (\%) of apoptotic cells } \\
\hline & & & $0 \mu \mathrm{M}$ & $5 \mu \mathrm{M}$ & $10 \mu \mathrm{M}$ & $20 \mu \mathrm{M}$ \\
\hline Curcumin & - & $7.30 \pm 0.4$ & & & & \\
\hline Control & + & $4.6 \pm 0.0 .3^{*}$ & & & & \\
\hline $\mathrm{SP}$ & - & & & $4.31 \pm 0.7$ & $4.88 \pm 0.1$ & $6.18 \pm 0.7$ \\
\hline 600125 & + & & & $3.93 \pm 0.2$ & $4.10 \pm 0.2^{*}$ & $4.43 \pm 0.3^{*}$ \\
\hline LY & - & & & $4.20 \pm 0.3$ & $4.98 \pm 0.5$ & $6.44 \pm 0.3$ \\
\hline
\end{tabular}

Serum-starved HSC were divided into two groups. One group was treated with curcumin $(20 \mu \mathrm{M})$, or LY294002, or PD98059, or SP600125 at the indicated concentrations, in DMEM with FBS (10\%) for $24 \mathrm{~h}$. The other group was pretreated with the specific PPAR $\gamma$ inhibitor PD68235 (PD') at $20 \mu \mathrm{M}$ for 30 min prior to the addition of curcumin $(20 \mu \mathrm{M})$, or one of the inhibitors at the indicated concentrations in the media with FBS (10\%) for an additional $24 \mathrm{~h}$. The rate of apoptotic cells was determined by flow cytometric analyses. Distributions (\%) of apoptotic cells in the cell cycle in each group were expressed as means \pm s.d. $(n=3)$. ${ }^{\star} P<0.05$ versus cells only with the same inhibitor at the same concentration, without the pretreatment with the PPAR $\gamma$ inhibitor.

PPAR $\gamma$ gene expression during HSC activation, whereas activation of PPAR $\gamma$ results in the interruption of the signaling pathways, leading to the inhibition of HSC activation. ${ }^{24}$ Our recent results supported the proposal and demonstrated an antagonistic relationship between the activation of TGF- $\beta$ signaling and the gene expression of PPAR $\gamma$ in HSC. ${ }^{24}$ The attention of the current study was paid to the role of PDGF and/or EGF signaling in the curcumin induction of PPAR $\gamma$ gene expression in activated HSC. Results in this report demonstrated that exogenous PDGF or EGF caused a dosedependent reduction in PPAR $\gamma$ gene expression in passaged HSC (Figure 1). Curcumin interrupted the signaling pathways for PDGF and EGF in activated HSC by reducing the level of tyrosine phosphorylation of PDGF- $\beta$ R and EGFR and inhibiting the activity of ERK, JNK and PI3/AKT (Figures 2 and 3). The activity of the PI-3K/AKT, ERK or JNK signaling pathway negatively regulated gene expression of PPAR $\gamma$ in activated HSC in vitro (Figures 4 and 5). The blockade of PI-3K/AKT, ERK or JNK signaling stimulated PPAR $\gamma$ expression (Figure 5). In addition, the interruption of the PI-3K/AKT, ERK and JNK signaling pathways resulted in the reduction in cell growth and the induction of apoptosis of activated HSC, which were partially eliminated by the inhibition of PPAR $\gamma$ activation (Figures 6 and 7 and Tables 1 and 2). Taken together, our results suggested that the activity of PDGF or EGF signaling might negatively regulate gene expression of PPAR $\gamma$ in activated HSC in vitro.

One of the dramatic features during HSC activation is enhanced cell growth, triggered by autocrine/paracrine acti- vation of the signaling for PDGF and EGF. ${ }^{3-6}$ The MAPK pathways and the PI-3K/AKT pathway are their major downstream signaling cascades. ${ }^{41-43}$ In this study, we hypothesized that the activation of PDGF and EGF signaling pathways might suppress gene expression of PPAR $\gamma$ in HSC. Curcumin might interrupt PDGF and EGF signaling, leading to the relief of the inhibitory effect on PPAR $\gamma$ gene expression in activated HSC. Our results in the present report demonstrated that activation of PDGF and/or EGF signaling suppressed gene expression of PPAR $\gamma$ and reduced the abundance of PPAR $\gamma$ in HSC (Figure 1). The activation of the downstream cascades of PDGF and EGF signaling, including $\mathrm{PI}-3 \mathrm{~K} / \mathrm{AKT}$, JNK or ERK, reduced the gene promoter activity of PPAR $\gamma$ (Figure 4). In contrast, the inhibition of the downstream cascades induced gene expression of PPAR $\gamma$ (Figure 5). This observation is supported by prior other studies. It was found that PDGF inhibited PPAR $\gamma$ transactivation activity in HSC transfected with a PPAR $\gamma$ cDNA expression plasmid, ${ }^{9}$ and that this inhibitory effect of PDGF was blocked by the inhibition of the MAPK signaling cascade. $^{9}$

We previously demonstrated that curcumin inhibited cell proliferation and induced apoptosis of activated HSC. ${ }^{22-24}$ The underlying mechanisms remain largely to be defined. The signaling pathways of PI-3K/AKT, ERK and JNK are critically relevant to cell proliferation and cell survival in many cell types, including in HSC. ${ }^{44-46}$ Curcumin reduced the level of tyrosine phosphorylation of PDGF- $\beta \mathrm{R}$ and EGFR and inhibited the activity of ERK, JNK and PI3/AKT 


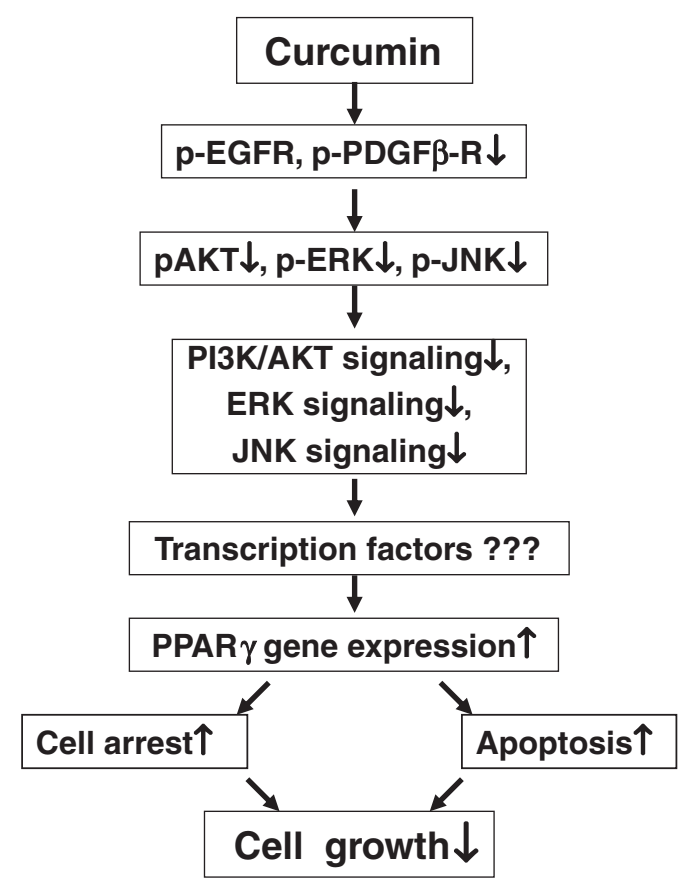

Figure 8 A schematic diagram of the role of the curcumin interruption of PDGF and EGF signaling in the induction of gene expression of PPAR in activated HSC. Curcumin reduces the level of receptor tyrosine phosphorylation and attenuates the activities of the downstream intermediators AKT, ERK and JNK, leading to the interruption of the signal transduction pathways of PDGF and EGF. These, together with other actions, collectively relieve the inhibitory effects on gene expression of $\operatorname{PPAR} \gamma$, leading to the inhibition of cell growth by inducing cell arrest and apoptosis.

(Figures 2 and 3), leading to the interruption of the mitogenic PDGF and EGF signaling pathways. Our results further demonstrated that the inhibition of PI-3K/AKT, ERK or JNK activity by specific inhibitors dose-dependently reduced cell growth and induced apoptosis of passaged HSC (Figures 6 and 7 and Tables 1 and 2). Moreover, it was of interest to observe that the inhibitory effect was, partially but significantly, abrogated by the pretreatment of cell with PD68235, a special inhibitor of PPAR $\gamma$ activity (Figures 6 and 7 and Tables 1 and 2). These results suggested that the induction of $\operatorname{PPAR} \gamma$ gene expression by curcumin and the stimulation of its activity might mediate the effect of the blockade of the PI-3K/AKT, ERK and JNK signaling pathways on the inhibition of cell growth of HSC. Additional experiments using siRNA to specifically block the curcumin induction of PPAR $\gamma$ expression will directly demonstrate the involvement of PPAR $\gamma$ gene expression in the inhibitory process.

Based on our prior and current observations, a model is proposed in Figure 8 to explain the mechanisms of curcumin in the induction of PPAR $\gamma$ gene expression and the inhibition of cell growth, focusing on the involvement of PDGF and EGF signaling in the process. Curcumin interrupts the signaling pathways for PDGF and EGF by reducing the level of receptor tyrosine phosphorylation and suppressing the activity of mitogenic PI-3K/AKT, JNK and ERK, leading to the induction of gene expression of PPAR $\gamma$ and the stimulation of its trans-activation activity. The latter mediates the curcumin inhibition of cell growth of activated HSC by inducing cell arrest and apoptosis. In summary, curcumin interrupts PDGF and EGF signaling, which might relieve their inhibitory effects on PPAR $\gamma$ gene expression, leading to the induction of gene expression of PPAR $\gamma$ and the reduction of cell growth of activated HSC in vitro. Additional experiments are necessary to clarify downstream transcription factors involved in the regulation of PPAR $\gamma$ gene expression. It bears emphasis that our results and this model do not exclude any other mechanisms in the curcumin induction of PPAR $\gamma$ gene expression and in the inhibition of HSC growth. The results in this report demonstrated that the activity of PDGF and EGF signaling negatively regulated gene expression of PPAR $\gamma$, which supported our original hypothesis that the interruption of the PDGF and EGF signaling pathways by curcumin might stimulate gene expression of PPAR $\gamma$ in activated HSC in vitro. These results provide novel insights into the mechanisms of curcumin in the induction of PPAR $\gamma$ gene expression and in the curcumin inhibition of HSC activation in vitro.

\section{ACKNOWLEDGEMENT}

This work was supported by the Grant RO1 DK 047995 from NIH/NIDDK to A Chen.

1. Kisseleva T, Brenner DA. Hepatic stellate cells and the reversal of fibrosis. J Gastroenterol Hepatol 2006;21(Suppl 3):S84-S87.

2. Friedman SL. Transcriptional regulation of stellate cell activation. J Gastroenterol Hepatol 2006;21(Suppl 3):S79-S83.

3. Pinzani M, Marra F. Cytokine receptors and signaling in hepatic stellate cells. Semin Liver Dis 2001;21:397-416.

4. Bachem MG, Riess U, Gressner AM. Liver fat storing cell proliferation is stimulated by epidermal growth factor/transforming growth factor alpha and inhibited by transforming growth factor beta. Biochem Biophys Res Commun 1989;162:708-714.

5. Czochra P, Klopcic B, Meyer E, et al. Liver fibrosis induced by hepatic overexpression of PDGF-B in transgenic mice. J Hepatol 2006;45: 419-428.

6. Pinzani M. PDGF and signal transduction in hepatic stellate cells. Front Biosci 2002;7:d1720-d1726.

7. Pinzani $M$, Milani $S$, Herbst $H$, et al. Expression of platelet-derived growth factor and its receptors in normal human liver and during active hepatic fibrogenesis. Am J Pathol 1996;148:785-800.

8. Komuves $L G$, Feren $A$, Jones $A L$, et al. Expression of epidermal growth factor and its receptor in cirrhotic liver disease. J Histochem Cytochem 2000;48:821-830.

9. Galli $A$, Crabb D, Price $D$, et al. Peroxisome proliferator-activated receptor gamma transcriptional regulation is involved in plateletderived growth factor-induced proliferation of human hepatic stellate cells. Hepatology 2000;31:101-108.

10. Marra F, Efsen E, Romanelli RG, et al. Ligands of peroxisome proliferator-activated receptor gamma modulate profibrogenic and proinflammatory actions in hepatic stellate cells. Gastroenterology 2000;119:466-478

11. Miyahara T, Schrum L, Rippe R, et al. Peroxisome proliferator-activated receptors and hepatic stellate cell activation. J Biol Chem 2000;275:35715-35722.

12. Citri A, Yarden Y. EGF-ERBB signalling: towards the systems level. Nat Rev Mol Cell Biol 2006;7:505-516. 
13. Perona R. Cell signalling: growth factors and tyrosine kinase receptors. Clin Transl Oncol 2006;8:77-82.

14. Chan TO, Rittenhouse SE, Tsichlis PN. AKT/PKB and other D3 phosphoinositide-regulated kinases: kinase activation by phosphoinositide-dependent phosphorylation. Annu Rev Biochem 1999;68:965-1014.

15. Hazra S, Xiong S, Wang J, et al. Peroxisome proliferator-activated receptor gamma induces a phenotypic switch from activated to quiescent hepatic stellate cells. J Biol Chem 2004;279:11392-11401.

16. Aggarwal S, Ichikawa H, Takada $\mathrm{Y}$, et al. Curcumin (diferuloylmethane) down-regulates expression of cell proliferation and antiapoptotic and metastatic gene products through suppression of IkappaBalpha kinase and Akt activation. Mol Pharmacol 2006;69:195-206.

17. Maheshwari RK, Singh AK, Gaddipati J, et al. Multiple biological activities of curcumin: a short review. Life Sci 2006;78:2081-2087.

18. Sharma RA, Gescher AJ, Steward WP. Curcumin: the story so far. Eur J Cancer 2005;41:1955-1968.

19. Chuang $\mathrm{SE}$, Kuo ML, Hsu CH, et al. Curcumin-containing diet inhibits diethylnitrosamine-induced murine hepatocarcinogenesis. Carcinogenesis 2000;21:331-335.

20. Park EJ, Jeon $\mathrm{CH}, \mathrm{Ko} \mathrm{G}$, et al. Protective effect of curcumin in rat liver injury induced by carbon tetrachloride. J Pharm Pharmacol 2000;52: 437-440.

21. Joe B, Vijaykumar M, Lokesh BR. Biological properties of curcumincellular and molecular mechanisms of action. Crit Rev Food Sci Nutr 2004;44:97-111.

22. $\mathrm{Xu} \mathrm{J,} \mathrm{Fu} \mathrm{Y,} \mathrm{Chen} \mathrm{A.} \mathrm{Activation} \mathrm{of} \mathrm{peroxisome} \mathrm{proliferator-activated}$ receptor-gamma contributes to the inhibitory effects of curcumin on rat hepatic stellate cell growth. Am J Physiol Gastrointest Liver Physio 2003;285:G20-G30.

23. Zheng S, Chen A. Activation of PPARgamma is required for curcumin to induce apoptosis and to inhibit the expression of extracellular matrix genes in hepatic stellate cells in vitro. Biochem J 2004;384:149-157.

24. Zheng S, Chen A. Curcumin suppresses the expression of extracellular matrix genes in activated hepatic stellate cells by inhibiting gene expression of connective tissue growth factor. Am J Physiol Gastrointest Liver Physiol 2006;290:G883-G893.

25. Camp HS, Chaudhry A, Leff T. A novel potent antagonist of peroxisome proliferator-activated receptor gamma blocks adipocyte differentiation but does not revert the phenotype of terminally differentiated adipocytes. Endocrinology 2001;142:3207-3213.

26. Chen A. Acetaldehyde stimulates the activation of latent transforming growth factor-beta1 and induces expression of the type II receptor of the cytokine in rat cultured hepatic stellate cells. Biochem J 2002;368:683-693.

27. Schmittgen TD, Zakrajsek BA, Mills AG, et al. Quantitative reverse transcription-polymerase chain reaction to study mRNA decay: comparison of endpoint and real-time methods. Anal Biochem 2000;285:194-204.

28. Fajas L, Auboeuf D, Raspe E, et al. The organization, promoter analysis, and expression of the human PPARgamma gene. J Biol Chem 1997;272:18779-18789.

29. Davis BH, Chen A, Beno DW. Raf and mitogen-activated protein kinase regulate stellate cell collagen gene expression. J Biol Chem 1996;271:11039-11042.
30. Mansour SJ, Matten WT, Hermann AS, et al. Transformation of mammalian cells by constitutively active MAP kinase kinase. Science 1994;265:966-970.

31. Chen A, Zhang L. The antioxidant (-)-epigallocatechin-3-gallate inhibits rat hepatic stellate cell proliferation in vitro by blocking the tyrosine phosphorylation and reducing the gene expression of platelet-derived growth factor-beta receptor. J Biol Chem 2003;278:23381-23389.

32. Ichiki T, Tokunou T, Fukuyama K, et al. 15-deoxy-Delta12,14prostaglandin $\mathrm{J} 2$ and thiazolidinediones transactivate epidermal growth factor and platelet-derived growth factor receptors in vascular smooth muscle cells. Biochem Biophys Res Commun 2004;323:402-408.

33. Artemenko Y, Gagnon A, Aubin D, et al. Anti-adipogenic effect of PDGF is reversed by PKC inhibition. J Cell Physiol 2005;204: 646-653.

34. Fajas L, Fruchart JC, Auwerx J. Transcriptional control of adipogenesis. Curr Opin Cell Biol 1998;10:165-173.

35. Sansal I, Sellers WR. The biology and clinical relevance of the PTEN tumor suppressor pathway. J Clin Oncol 2004;22:2954-2963.

36. Reif S, Lang A, Lindquist JN, et al. The role of focal adhesion kinasephosphatidylinositol 3-kinase-akt signaling in hepatic stellate cell proliferation and type I collagen expression. J Biol Chem 2003;278:8083-8090.

37. Schnabl B, Bradham CA, Bennett BL, et al. TAK1/JNK and p38 have opposite effects on rat hepatic stellate cells. Hepatology 2001;34: 953-963.

38. Schuppan D, Atkinson J, Ruehl $M$, et al. Alcohol and liver fibrosispathobiochemistry and treatment. Z Gastroenterol 1995;33:546-550.

39. Wong L, Yamasaki G, Johnson RJ, et al. Induction of beta-plateletderived growth factor receptor in rat hepatic lipocytes during cellular activation in vivo and in culture. J Clin Invest 1994;94:1563-1569.

40. Friedman SL, Yamasaki G, Wong L. Modulation of transforming growth factor beta receptors of rat lipocytes during the hepatic wound healing response. Enhanced binding and reduced gene expression accompany cellular activation in culture and in vivo. J Biol Chem 1994;269:10551-10558.

41. Claesson-Welsh L. Platelet-derived growth factor receptor signals. J Biol Chem 1994;269:32023-32026.

42. Jorissen RN, Walker F, Pouliot N, et al. Epidermal growth factor receptor: mechanisms of activation and signalling. Exp Cell Res 2003;284:31-53.

43. Marshall CJ. Specificity of receptor tyrosine kinase signaling: transient vs sustained extracellular signal-regulated kinase activation. Cell 1995;80:179-185.

44. Cantley LC. The phosphoinositide 3-kinase pathway. Science 2002;296:1655-1657.

45. Pages G, Lenormand P, L'Allemain G, et al. Mitogen-activated protein kinases $\mathrm{p} 42 \mathrm{mapk}$ and $\mathrm{p} 44 \mathrm{mapk}$ are required for fibroblast proliferation. Proc Natl Acad Sci USA 1993;90:8319-8323.

46. Mitsui H, Takuwa N, Kurokawa K, et al. Dependence of activated Galpha12-induced G1 to S phase cell cycle progression on both Ras/mitogen-activated protein kinase and Ras/Rac1/Jun N-terminal kinase cascades in NIH3T3 fibroblasts. J Biol Chem 1997;272: 4904-4910. 